\title{
Multi-disciplinary internet-based platform in optimizing college English teaching
}

\author{
Wei Wang ${ }^{1}$, Jianhua Zhai ${ }^{1}$ \\ Hebei University of Science and Technology, Shijiazhuang, CHINA \\ wangweikd@163.com,jhzhai05@yahoo.com.cn
}

\begin{abstract}
This paper analyses the current situation of Internet application in college English teaching. It not only points out many problems that exist in current college English teaching but also puts forward many effective methods to deal with its problems especially puts forward a systematic platform which mainly featured as multi-path, personalized, multilevel, serial "Multi-disciplinary platform". By establishing this platform aided by Internet will finally perfect college English course content, and deepen the reform of college English teaching radically.
\end{abstract}

Keywords: Multi-disciplinary, Internet, college English

\section{Introduction}

At present, we are enjoying a rapid development that brought by high technology in our information age. It is obvious that the issues of economic competition and cooperation, comprehensive national strength promotion, and innovative talents cultivation have called for more specific and higher requirements for various carrier of this age. Moreover, after joining the WTO, diverse communication between China and other countries in the world is becoming more and more frequent, which need more inter-disciplinary talents who are supposed to master both relative professional knowledge and proficient English language skills. In this context, English teaching plays the key role for both educators and students. There is no doubt that teaching objectives should be focused on shaping people with great spirit and cultivating people with great innovation. Therefore, in information age the people in its true sense should be defined as not only a person with great ideological and political quality but also with strong professionalism and capability of harnessing its profession, which only by orderly innovative college education could make it happen. College English teaching bears the brunt of accomplishing this mission that composed of our national education process.

\section{Current situation of college English teaching}

It is universally acknowledged that the final goal of college English teaching is to teach students with English language and how to communicate with it successfully. However, the degree of mastering English for today's college students has forged a gap with society's demands, which cannot meet the requirements for development of economic construction and social situation. In order to effectively understand what do we face up with current college English teaching, it is ne- 
cessary to clarify some major problems exist in it.

\subsection{Linear-thinking mode of college English teaching}

Linear-thinking mode could be defined as a straight, unidirectional and changinglack thinking way, which in another words means roles of students and teachers. To simplify what we define is teacher-dominating mode, which features passive reception of students followed by traditional practice and exercises of writing, reading and sentence patterns etc. Teachers play the role as an authority or leader and comparatively students as receiver who passively answered and followed. Unfortunately this trend of teaching mode still dominates over the whole teaching field that result in lacking of learning motivation, independent thinking and creative thinking.

\subsection{Multi-media aided mode of college English teaching}

Modern educational technology, especially multi-media technique has already widely applied in college English teaching classroom. Obviously with the help of multi-media technique all the teachers could free from traditional chalks and blackboard meanwhile students could enjoy more audio or visual popular information that really facilitate teaching process in some degree. However, a great majority of teachers has deeply misunderstood the essence and connotation of multimedia who just edited their own PowerPoint slides and displayed one by one without any interaction among all teaching activities, which will definitely restrict maximum efficiency of multi-media teaching.

\subsection{Graded-teaching mode in college English teaching}

Students are required to take an exam when they are entering into college. Ac- cording to the test scores all students will be divided into different levels (usually A, B and C), which could satisfy certain students' need who have solid foundation of English language and more learning abilities. As a matter of fact, a lot of students are not in favours of this teaching mode after a survey that greatly affect their learning interest and incentive. In addition, the course after grading-teaching such as translation, interpretation, western culture, business English and relative optional courses are seriously falling behind students' needs even can not be offered, which could barely meet the needs of students language development so that real comprehensive practical language skills and students' personality requirements are greatly damaged.

\subsection{Internet-based autonomous learn- ing in college English teaching}

This mode mainly depends on students' autonomous self-study facilitated by various Internet resources. On the one hand, limited computer resources cannot guarantee all students have access to make use of this resource, especially the whole process of learning only values the result instead of supervising its quality which discount the learning effect greatly. On the other hand, this mode still lays on an awkward situation or ideal state for both teacher and students, which we can tell from students' whatever feedbacks to this mode, in details, all diverse Internet learning resources are not arranged, selected, edited or recommended in a good way so that resources cannot be used in its upper limit not even teachers' negotiating management.

\section{Countermeasures to problems in col- lege English teaching}

\subsection{Changing linear-thinking mode into non-linear-thinking mode}

Under this mode teachers' dominating 
role as a guide should be emphasized. First, humanistic qualities of teachers are supposed to be enhanced as much as possible plus a team of high-qualified teachers construction. Serious responsibility of career, innovative spirit and higher openness awareness or revolutionary belief should be considered as key condition to achieve success in process of college English teaching and learning. Teachers who are role models for students to watch and learn also continue with polishing their major knowledge and learning cross-disciplinary knowledge in order to interact with students to get a mutual win-win consequence and make progress together.

\subsection{Changing teacher-dominant mode into teacher-host mode}

To have a correct and clear incentive for learning is the premises of succeed in learning any disciplines. Most students regard English learning as a tool mastering process that main purpose of learning is to pass some exams for find a good job. Therefore, they hold an attitude that it is an unwilling or compulsory requirement they have to deal with. They never consider systematic learning plan or effective learning methods actively so that they behold emotional weariness. Considering this, we are demanded to strive for students' learning initiatives as well as guide them with self-planning.

\subsection{Optimising autonomous learning platform system}

To begin with, we need to set up brandnew learning mode such as studentcomputer-student mode, BBS learning mode and Free Learning mode etc., which will contribute to role changing between teachers and students smoothly. Then, to strive for support and fund from authorities such as hardware improvement of Internet environment, multimedia learning classroom and autonom- ous learning centres etc., which will provide all sorts of resources to satisfy students' interest and learning needs. Besides, to equip a team of technician with professional information technology knowledge can fully ensure backup work for both teachers and students. Only by integrating teaching resources, learning platforms, learning system, satellite television and playing its negotiating and managing function can we finally find the way to accomplish optimising college English teaching to its maximum.

\section{Application of multi-disciplinary Internet-based platform}

In 2007, Chinese Ministry of Education announced College English Curriculum Requirements, which are greatly based by all college English teaching. Therefore, some countermeasures here are put forward to cope with the problems for the purpose of meeting the national requirements for college English teaching.

Firstly, to build up and forge the "multidisciplinary" English teaching platform in the all-round way. Secondly, in order to guarantee the successful operation of teaching platform system we are determined to make out detailed teaching plans on base of the actual need of each broad platform, to compile relevant teaching extensive textbooks and teacher's tutorials, to establish corresponding teaching team and conduct teacher's continuing training etc at the same time. Non-English major students need to take part in the placement test at the beginning of college entrance, which are classified into three levels. Then, on the basis of their test scores and teachers' suggestion they step into the relevant levels to study English, which contain College English viewing, listening, speaking course and College English reading, writing, translating course. The teaching contents will be condensed accordingly. Thirdly, to estab- 
lish immersed English learning platform and environment both in class and after class. By improving and perfecting the college English autonomous learning platform we could improve the students autonomous learning ability, organize diverse extra-curriculum activities, take advantage of numerous rich English learning resources so that the authentic learning environment can be made, the mutual assistance project can be executed, the hidden curriculum could be forged and the better individualized English teaching could be fully executed.

\section{Conclusion}

In fact the target or objective of college English teaching could be defined as cultivating students' comprehensive language quality, enhancing their international academic communication capability, improving their humanistic quality with regards to language and boosting their autonomous learning ability. Therefore, the reform of college English curriculum must be cleared in terms of courses orientation, the analysis of requirements needs to be reasonable, the design for curriculum should be scientific as well as rich learning materials, teacher's aptitude and integration with academic English. Based on modern Internet technology, to construct a multi-disciplinary teaching platform featuring with interactive, flexible time and space, active learning style is bond to optimise college English teaching to the extreme.

\section{Acknowledgement}

This research was supported and funded by Colleges and Universities in Hebei Province English Teaching Reform Project 2012. (No.HB12Y003)

\section{References}

[1] Cai Jigang.. ESP and Tendency of College English Teaching Development. Foreign Language World, vol.2, pp. 22-28, 2004.

[2] Hu Zhuanglin, "Basic Theory Discussion on Teaching Requirements of College English in a way of Individualization, Coordination, Modularisation and Hypertext", Foreign Language Teaching and Research, vol.5, pp. 345-35, 2004. 